incorporation of labelled amino-acids into brain proteins during hibernation. The biochemical basis of the dramatic increase in body temperature and metabolic rate during arousal from hibernation was discussed by Dr. L. Mokrasch (Waverley). Changes in the activities of oxidative and glycolytic enzymes do not appear to play a significant part, but it appears possible that activation of phosphorylase, and enzymes (adenosine triphosphatese and acyl phosphatase) capable of cleaving high-energy compounds may be implicated in the mochanism of heat production during arousal.

The distribution of neurohypophyseal peptides in different classes was traced by Prof. H. Heller (Bristol). In the cyclostomes, fish, amphibia and birds, the principal antidiuretic peptide is 8-arginineoxytocin (vasotocin); in most mammals, including the ruminants, arginine-vasopressin is typical; whilo in the pig and hippopotamus lysine-vasopressin is characteristic. A basic phylogenetic division in distribution of the octapoptides may be traced, but important exceptions to the general pattern exist.

Dr. D. B. Carlisle (London) posed a provocative question for the participants in the title of his paper "What makes tho Shrimp's Heart Beat Faster?" One answer proved to be "another shrimp!": but in all, six substances (including two polypeptides, and four indole derivatives) isolated from extracts of the shrimp pericardial organ will produce the same effect. The most potent compound has been identified as 5:6-dihydroxytryptamine. This compound probably serves to produce instantaneous effocts on the heart beat, while the polypeptides appear to account for long-term responses during prolonged stress. Other papers were concerned with the distribution and functions of acetylcholine, indoles, cate- cholamines and other possible neurotransmitter substances in differont species.

In the final session, devoted to comparative neuropharmacology, the basis of specios differences in the sensitivity to drugs was considered. The selective toxicity of piporazine, an anthelmintic agent, was shown by Dr. E. Bueding (Baltimore) to be related to its ability to produce a selective neuromuscular blocking action in Ascaris without affocting the neuromuscular junction of the mammalian host. As pointed out by Dr. D. Richter (Carshalton) in the final discussion, the practical value of comparative neurochemistry is evident in the exploitation of such intraspecios differences for the development of now anthelmintics and pesticides.

Many excellent papers and interesting commentaries have been nocessarily omittod from this brief report. I would be remiss, however, if I failed to commont on the fine tissue culture experiments on in vitro myelin formation by Prof. Margaret Murray (New York), the elegant electronmicrographs of norve membranes by Dr. J. D. Robertson (Waverley), the stimulating speculations concerning the macro-molecular basis of coding in the memory mechanism by Prof. F. O. Schmitt (Boston), and the techniques used by Dr. H. Blaschko (Oxford) in estimating the amine oxidase activity of the Malpighian tubules in the cockroach. The proceedings of the Symposium are being published in the form of a book, Comparative Neurochemistry, edited by Dr. D. Richter.

During our stay, the participants were entertained at receptions and banquets by the Mayor of St. Wolfgang, the Mayor of Salzburg and the Government of Upper Austria. The hospitality of our Austrian hosts and the beauty and gaiety of the Salzkammergut made this Symposium an exccedingly enjoyable as well as scientifically profitable occasion. W. C. McMurRay

\title{
THE COLONIAL DEVELOPMENT CORPORATION
}

\begin{abstract}
$\mathrm{T}$ HE annual report and statement of accounts of the Colonial Development Corporation for the year ended December 31, 1961*, follows the pattern of the previous report. However, the form of the accounts has been altered to givo offect to the changes in financial arrangements which the Government announced in April 1961; deferred Government interest currently accruing in 1961 is charged for the first time in the accounts to the extent of some $£ 800,000$. The 102 approved projects at the end of the year, totalling $£ 115,770,000$, included thirteen new projects totalling some $£ 10$ million, of which the largest were the Swaziland Railway Board (£4.25 million), the Trinidad Mortgage Agency Co., Ltd. (£1-97 million), the Land Development and Settlement Board, Kenya ( $\$ 1.5$ million) and Northern Rhodesia Africa Housing ( $\$ 1$ million). Four projects were abandoned and one existing project was split into two projects. Of the total commitmonts, $£ 16.454$ million was in the Caribbean region, $£ 20.315$ million in the Far East, $£ 22.484$ million in East Africa,

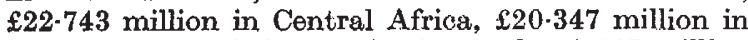
the High Commission territories, and $£ 13.427$ million in West Africa. Functionally, 54.8 per cent of the committed capital in 1961 was for basic development,
\end{abstract}

*Colonial Development Corporation. Annual Report and Statement of Accounts for year ended 31st December, 1961. Pp. vi + 90. (London H.M. Stationery Office, 1961). 5s. $6 d$. net.
34.4 per cent for primary production and processing, and 10.8 per cent for commerce and industry.

While the British Exchequer remains the chief source of the Corporation's finance, a steadily increasing part of its investment is financed either by self-generated funds or by loans from sources other than the Exchequer. It is emphasized, however, that the Corporation's operations are more immediately likely to be restricted by territories becoming independent with consequent exclusion of the Corporation, despite their continued need for its help, than by shortage of funds, and the total of new projects under serious consideration fell from 38 to 26 during the year. The present terms of reference in independent territories are, however, now under review.

The report indicates the type of schome which will receive serious consideration by the Corporation once compliance is established with the Corporation's normal powers. Priority is increasingly given to schemes which help the inhabitants of the country to establish themselves as members of an economically self-supporting and ordered community, for example, agricultural small-holder projects, housoholder mortgage finance companies and local industrial development agencies. Through the small-holder sohemes also, production of tea in Konya, palm oil in Malaya, tobacco at Kasungu, Nyasaland, and sugar in Swazi- 
land should yield an increasing volume of cash exports. The success of these schemes depends in the long run on other aspects of the territorial economy reaching a certain level of development and affording such projects as power, water supplies, transport and nucleus agricultural estates, the means to investigate and establish the cultivation and management techniques appropriate to small-holder crops, and that high priority be given to production industries which generate the cash exports to service capital investment overseas. The Corporation is already committed to nearly $£ 6$ million in some fourteen projects for local industrial development agencies.

Stress is also laid on the way the Corporation is placed to keep in touch with local circumstances and views. The Corporation believes that the presence on the spot of Corporation staff, ready to share the risks of local ventures by equity investment, en- genders a sense of partnership not present when development finance is provided only as block loans from abroad. The maintenance of the Corporation's offices and staffs in times of rapid political change certainly provides an essential element of economic continuity; the extent of the management organization implied in the fact that the Corporation itself has at least some responsibility fot the management of more than half the 102 continuing projects is seldom realized. Although there is less reference in this report to this training function, the importance of making every effort to train local men for executive posts of responsibility is fully recognized. Some success in this direction is reported in the Far East, in the Caribbean and West Africa, while in other parts of Africa the Corporation is concentrating, as a first step, on providing scholarships at agricultural and technical colleges and on project training schemes.

\section{MINERAL TECHNOLOGY AT THE IMPERIAL COLLEGE OF SCIENCE AND TECHNOLOGY}

YN 1952 the University of London established at 1 the Royal School of Mines a course in mineral technology leading to a B.Sc. degree, the first undergraduate course of its kind in the Commonwealth and one of the first in the world. In 1961 a new chair was founded (see Nature, 190, 1153; 1961) and the inaugural lecture of Prof. M. G. Fleming has now been published by the Imperial College of Science and Technology*.

Mineral technology, embracing as it does both the engineering and the scientific aspects of the separation of the valuable mineral constituents from their ores, has its origin in prehistoric times with man's selection and dressing of stones for his tools and weapons, and its long history is closely linked with that of civilization itself. Silver from the mines at Laurium built the Greek fleet that defeated Xerxes, and copper from Falun financed Sweden's part in the Thirty Years' War. During the twentieth century, more irreplaceable minerals have been consumed than in the whole previous history of the Earth. From 1911 to 1959 the world production of iron ore increased from about 130 million tons to 406 million, nickel ores from 24 to 290 thousand tons and sulphur and pyrites from some three million tons to eight times that figure. This expanding demand has necessitated the treatment of increasingly low-grade and complex deposits which in the past would have

- Mineral Technology-Progress and Problerns. Inaugural Lecture, December 5, 1961.) Pp. 79-98. By Prof. M. G. Fleming (London: Imperial College of Science and Technology. Distributed by been considered valueless, and mineral dressing which even fifty years ago was still essentially an art has now become a branch of industrial science in its own right. How important it is for Britain, not only to keep abreast of the latest developments in this field but also to play the fullest part in new research of all kinds, is evidenced by the fact that Britain no longer has control of enormous quantities of raw material which is necessary for her existence as a leading industrial nation. As a result of the granting of independence to many territories much more than half the mineral production of former members of the Empire has already passed out of Britain's hands.

It is in order to play its part in this that Prof. Fleming's Department has come into existence. Quite apart from its undergraduate work, the investigations already under way range from the determination of heats of adsorption, a study of the mechanism of adhesion of colloidal particles and the kinetics of solvent extraction, to dense-medium separation in hydrocyclones and the beneficiation of concentrates by pelletizing, roasting and leaching. This most interesting inaugural lecture concludes with an account of work on flotation in which the necessary reagents are introduced as a fine spray, the separation of ore from gangue being further improved by the application of an appropriate electrostatic charge whereby the droplets of reagent are attracted to the valuable minerals and actually repelled from the particles of gangue.

F. C. THOMPSON

\section{EVALUATION OF THE CARCINOGENIC HAZARDS OF FOOD ADDITIVES}

\footnotetext{
THE Joint Food and Agriculture Organization/ World Health Organization Expert Committee on Food Additives met in Geneva during December 12-19, 1960, and, in its fifth report* has recommended the following general basic principles:

*W.H.O. Tech. Rep. Ser., No. 220 (H.M.S.O., 1961).
}

(1) Food additives should be used for the benefit of the consumer; they should not be permitted for any deceptive or misleading purpose.

(2) The use of certain food additives is justified since the present position with respect to world food supplies makes it imperative that good techni- 